University of Nebraska - Lincoln

DigitalCommons@University of Nebraska - Lincoln

$11-2000$

\title{
Public Education Cost Frontier Models: Theory and An Application
}

John E. Anderson

University of Nebraska-Lincoln, JANDERSON4@UNL.EDU

Mahbubul Kabir

Lyon College, mahbubul.kabir@lyon.edu

Follow this and additional works at: https://digitalcommons.unl.edu/econfacpub

Part of the Economics Commons

Anderson, John E. and Kabir, Mahbubul, "Public Education Cost Frontier Models: Theory and An Application" (2000). Economics Department Faculty Publications. 41.

https://digitalcommons.unl.edu/econfacpub/41

This Article is brought to you for free and open access by the Economics Department at DigitalCommons@University of Nebraska - Lincoln. It has been accepted for inclusion in Economics Department Faculty Publications by an authorized administrator of DigitalCommons@University of Nebraska - Lincoln. 


\title{
PUBLIC EDUCATION COST FRONTIER MODELS: THEORY AND AN APPLICATION
}

\author{
John E. Anderson \\ Department of Economics, University of Nebraska, Lincoln, NE 68428 \\ Mahbubul Kabir \\ Department of Business and Economics, Lyon College, Batesville, AR 72503
}

\begin{abstract}
We examine the cost structure of public schools in this paper, using frontier cost models that enable us to estimate sources of inefficiency. A two equation stochastic frontier model is presented that can be used to explain both cost and the sources of inefficiency. Using that model and data for public schools in Nebraska over the period 1989-92, we estimate cost frontiers for the districts. Estimated cost frontier information is then used in estimating school district need for purposes of computing state aid, illustrating an important potential application of such information.
\end{abstract}

Key Words: education cost functions, frontier estimation, education finance, education aid, fiscal disparity

JEL Classification: H41, H77, I21, I22, D24 


\section{INTRODUCTION AND BACKGROUND}

Over the past two decades across countries and regions serious questions have been raised about performance in the public education sector. In the United States, growing reluctance on the part of taxpayers at the local level to pay increasing taxes has become pervasive. School district expenditure, its mode of funding, and social equity effects on educational outcomes have all been the subject of numerous studies. In particular, a number of recent studies have examined the economic efficiency of public schools. One of the common analytic tools used in these studies is the estimation of the cost structure of the educational production process. Knowledge of cost structure and estimates of efficiency should shed light not only on the expenditure side, but also on efforts to derive useful policy implications for the funding and equity in public education.

School districts in Nebraska, like many other states, have been dependent on property tax and state/federal aid for their funding. Believing that school district funding was too dependent on the property tax, and desiring to achieve additional equity across districts, a commission was instituted in 1988 in Nebraska to formulate policies for financing, expenditure, and equity. Part of the motivation for the commission was a desire to avoid court-ordered reform due to perceived inequality in funding across districts, as had been experienced in a number of states in the previous decade. It was perceived to be time to overhaul the state aid mechanism for funding public schools, taking into account appropriate measures of school district need and resources.

The Nebraska school aid formula was revised in 1990-91 to rationalize state aid, basing aid on the difference between school district need and resources. The definition of district need prescribed was quite primitive, simply defining need as the average expenditure of districts of roughly similar size. Districts were classified by size, with the two largest districts in the state, Omaha and Lincoln in their own classes. Hence, district need was simply defined as district expenditure for these specific districts. Districts in classes composed of more than one district, have need defined as the average expenditure of the districts in the size class. This approach to state aid funding is not unique to Nebraska, but does illustrate the critical role to be played by proper 
estimates of school district need.

Within this context, our paper is an attempt to study the cost structure and efficiency of each of the Nebraska school districts included over the period of 1989-92. The new element in this research approach is to focus on frontier cost, rather than on average function cost, to derive insights about the cost structure and efficiency performance of Nebraska school districts. In this paper, we first present a summary of the underlying theory of public education cost function estimation. Then, we suggest an alternative method of cost function modeling and estimate the proposed cost frontier model in the case of Nebraska school districts. We explain the usefulness of the cost frontier approach in exploring cost structure and in measuring efficiency of public education. Finally, we suggest ways to improve public education finance mechanisms, intended to address fiscal disparities across districts, by examining the potential use of frontier cost estimates of district need in the state aid formula.

\section{THEORY OF PUBLIC EDUCATION COST FUNCTION ESTIMATION}

\section{The Average Response Function and the Concept of a Frontier Function}

The approach adopted in this paper to examine cost and fiscal issues of Nebraska school districts is different from that used in prior studies based on ordinary least squares (OLS) estimation of educational cost structure. Other econometric methods have also been suggested to improve the unbiasedness, efficiency, and consistency of estimators. See Downes and Pogue (1994), for example. For non-statistical frontier methods, see Klitgaard and Hall (1975), Levin (1976), Sengupta and Sfeir (1986), McCarty and Yaiswarng (1993). For parametric statistical frontiers, see Barrow (1991), Wyckoff and Lavinge (1991), and Chakraborty et al. (1996).

OLS estimation of a cost function for school districts involves fitting an average response function through the scatter of school district points. The implicit educational production technology estimated by this method is thus an average technology for school districts in the sample. Estimated coefficients for the variables 
of such a cost model reflect an average technology, not a technology reflecting the best that can be done with given resources. Farrell (1957) first recognized that the traditional econometric techniques (represented by the socalled average response function of OLS) do not appropriately estimate what is needed in many production and cost studies, based on the microeconomic definitions of cost and production functions. His idea was to fit a curve that would pouch all the observed points above the curve, in the case of a cost function, or envelope all the observed points below the curve in case of production function. Hence, Farrell's suggested frontiers represent the best available technology and his concept of a frontier function was suggested as method to measure the efficiency of enterprises. However, the average response function has been the focus of the mainstream econometric literature in production and cost economics. If we assume all firms are efficient then no doubt, such an average function would be adequate for describing the efficient technology involved. If inefficient production units exist, however, then Farrell's frontier concepts are not only relevant, but also necessary for conducting appropriate analysis. It is our contention that such methods are appropriate in estimating public education cost functions.

\section{Advantages of Frontier Modeling}

A statistical deterministic cost frontier can be adopted from Afriat (1972) written as $\log [\mathrm{C}]=\log [\mathrm{C}(\mathrm{y}$, $\mathrm{p})]+u$, where $\log [\mathrm{C}]$ is the natural logarithm of cost per pupil and $u$ is a nonnegative random variable $(u \geq 0$, i.e., strictly one-sided distribution,) representing cost inefficiency effects. Output is denoted y and input prices are

denoted p. Here, the cost frontier is the non-stochastic part, $\log [C(y, p)]=C^{f}$, and as such it is called the deterministic frontier. In this case, residuals are entirely attributed to inefficiency. The most damaging criticism cast on this model is that it ignores the regular noise term. For this reason and others cited in Coelli (1995), econometricians have abandoned the deterministic frontier for efficiency measurement.

In a stochastic cost frontier model there are two error terms: one symmetric and another asymmetric. Schmidt (1985-86) explains that the first term is a regular symmetric noise term representing "events not under 
the control of the firm, such as luck, weather, etc." The error term is assumed to be independently and identically distributed normal with zero mean and constant variance: $v \sim i i d \mathrm{~N}\left(0, \mathrm{o}_{v}{ }^{2}\right)$. Second, cost inefficiency effects are captured in an asymmetric error term $u$, independent of $v$, and are assumed to be arising from an iid truncatednormal or exponential distribution ( $u \geq 0$; half-normal or exponential, as in Schmidt and Lovell (1979)). The stochastic frontier model is represented as:

$$
\log [\mathrm{C}]=\log [\mathrm{C}(\mathrm{y}, \mathrm{p})]+(v+u)
$$

The combined error term $(v+u)$ has a range of $-_{\infty}$ to ${ }_{\infty}$, but the distribution is skewed and has a non-zero mean, given by the mean of the composite error term $(v+u)$. Addition of a noise term provides superiority for the stochastic model, in comparison with a deterministic frontier model. A stochastic model allows us to conceptualize both favorable and unfavorable random conditions $(v)$ separately from inefficiency effects $(u)$. This feature provides a way to measure efficiency less arbitrarily than a deterministic model.

The composite nature of the error term in the stochastic model also has very helpful implications in the analysis of school district cost structure. For example, Bradbury et al. (1984) and Downes and Pogue (1994) included environmental cost factors in cost models, and thus tried to identify the cost differential between local jurisdictions (municipalities, school districts, cities and towns) because of uneven environmental cost factors. In the case of education, it might be that in one school district there is an extra cost of \$R per pupil due to a particular environmental cost factor such as the presence of special-need students. There may be agreement among state and local officials that this $\$ \mathrm{R}$ per pupil should be covered by the state aid formula. However, it is reasonable to ask under what random favorable or unfavorable conditions a particular school district is operating. It could be that the school district is operating under a favorable condition that helps the school district save cost in the amount of $\$ Q$ per pupil. In this situation, the school aid formula should be adjusted for the required expenditure of $\$ \mathrm{R}$ per pupil to $\$(\mathrm{R}-\mathrm{Q})$ per pupil. In a similar way, it can be argued that the adjusted extra cost per pupil would be $\$(\mathrm{R}+\mathrm{Q})$ in an unfavorable situation. The opportunity to account for favorable and 
unfavorable conditions in the environment of school districts is possible because of the composite error structure $(u+v)$ in stochastic cost frontier and can then be instrumental in adjusting the school aid formula. Thus, besides providing an efficiency measure for school districts, the stochastic cost frontier approach has significant potential for rationalizing school aid.

A geometric exposition of cost frontier concepts, following Battese (1992), is illustrated in Figure 1. $C^{f}$ represents the deterministic part of a cost frontier $\mathrm{C}(\mathrm{y}, \mathrm{p}, \hat{\mathrm{a}})$ in the figure. Three school districts denoted with scale subscripts $\mathrm{i}, \mathrm{j}$, and $\mathrm{k}$, illustrate three possible situations in terms of their relative size of inefficiency and random favorable/unfavorable condition with which they are operating. School district k's stochastic cost frontier lies above the corresponding deterministic part, indicating a random unfavorable operational condition $\left(v_{\mathrm{k}}>0\right)$. Inefficiency $u_{\mathrm{k}}$ contributes to placing district $\mathrm{k}$ further above the cost frontier $\mathrm{C}$. In the case of school district $\mathrm{i}$, the stochastic cost frontier is below the deterministic frontier line implying a random favorable condition $\left(v_{\mathrm{i}}<0\right)$. However, inefficiency of the school district $\mathrm{i}$ offsets the favorable condition $\left(u_{\mathrm{i}}>v_{\mathrm{i}}\right)$ and causes the observed cost to be higher than the deterministic cost frontier. School district $\mathrm{j}$ 's situation is similar $\left(v_{\mathrm{j}}<0\right)$ to school district $\mathrm{i}$, except that j's efficiency level is relatively better $\left[\left(u_{\mathrm{j}} / v_{\mathrm{j}}\right)<1\right.$ and $\left.\left(u_{\mathrm{i}} / v_{\mathrm{i}}\right)>1\right]$ than school district $\mathrm{i}$, resulting in an observed cost lower than the deterministic cost. This description of the relative size of $u$ and $v$ terms helps illustrate the potential of the stochastic frontier function in addressing the issue of fiscal disparities among school districts.

Favorable and unfavorable conditions are random, by definition, so they should not affect the specification of the model. As long as inefficiency effects are random they should not cause a serious specification problem. However, if we assume that observed inefficiency is systematically dependent on controllable factors, and we do not incorporate them in the cost model, they will cause specification error.

Factors systematically causing inefficiency eventually affect cost. If we could account for the fixed portion of inefficiency it would improve the quality of estimations. Attempts to incorporate variables that explain 
inefficiency directly within the cost function might introduce other econometric problems (e.g., multicollinearity). With completely deterministic inefficiency (different from the concept of deterministic frontier), however, OLS estimation would suffice if we could include the variables that systematically affect inefficiency. Unfortunately, one limitation of this approach is that the inefficiency effects cannot be singled out. A one-equation stochastic frontier model is obviously irrelevant when inefficiency effects are modeled with a systematic component only. But if the inefficiency effects consist of systematic and random components, then we need to be more careful about specification. In this circumstance, a one-equation stochastic frontier model would seem to be more vulnerable to misspecification.

Reifschneider and Stevenson (1991) addressed the question of "whether inefficiency occurs randomly across firms, or whether some firms have predictably higher levels of inefficiency than others." They argued "if efficiency ... is not totally random, then it would be possible to identify factors that contribute to the existence of inefficiency." They developed a single-step MLE technique similar to, but independent of, the Kumbhakar et al. (1991) technique. Their empirical results for the cost frontier of an electric utility suggest that including both systematic and random components in the inefficiency error term is superior. A two-equation model, including equation for inefficiency effects, as proposed by Kumbhakar et al. (1991) and Reifschneider and Stevenson (1991) (extended further to panel data by Battese and Coelli (1993)), appears to be better conceptualized to handle the anticipated specification problem. The first equation of a two-equation model can be written as equation (1) where $v \sim i i d \mathrm{~N}\left(0, \hat{\mathrm{o}}_{v}{ }^{2}\right)$, and $u$ comes from the distribution $\mathrm{N}\left(\ddot{\mathrm{a} Z}, \dot{\mathrm{o}}_{u}{ }^{2}\right)$ which is truncated at zero. Z is a column vector of firm-specific factors that explain the systematic part of firm inefficiency and ä is a row vector of corresponding parameters. In the second equation the error term $u$ is specified as

$$
u=\mathrm{f}(\ddot{\mathrm{a} Z})+w,
$$

where $w$ represents the random component of inefficiency, distributed as a normal random variate $\mathrm{N}\left(0, \dot{\mathrm{o}}_{u}{ }^{2}\right)$, truncated at $-\mathrm{f}(\mathrm{a} Z)$. This two-equation model has another important aspect. It can address heteroskedasticity 
that may be present in the efficiency distribution. In the public school cost function context, it is apparent that the variance in cost per pupil is not constant, but depends on school district size.

Battese and Coelli (1993) adopted and extended the Kumbhakar et al. (1991) model of $u_{\mathrm{i}} \sim \mathrm{N}\left(\mathrm{äZ}, \mathrm{o}_{u}{ }^{2}\right)$ in light of Huang and Liu (1994). Then Coelli (1994) developed a computer program called Frontier 4.1 for the numerical solution of the model. Battese and Coelli (1993) and Coelli and Battese (1996) extended this approach for panel data. Under the assumption that inefficiency effects are stochastic, the panel data model allows a distinction between intertemporal variation in technical efficiencies and technical change over time. Within the two-equation stochastic frontier framework, Huang and Liu (1994) emphasized the notion of non-neutral shifting of the average response function by allowing the interaction between firm-specific variables and the right hand side variables of the frontier function. Their paper suggests that a discovery of non-neutral shifting of the average function in an empirical investigation would further weaken the usefulness of the average response function as an analytical tool. In this case, OLS cannot even indicate the shape of the frontier function.

Therefore, it is an empirical matter to determine whether an OLS model with only deterministic inefficiency, a one-equation stochastic model, or a two-equation stochastic model, is best supported by the data. Theory suggests that the two-equation model may be more promising in analyzing school district cost structure and in deriving aid formula implications.

\section{Cost Function, Efficiency, Production, and Fiscal Disparity in Education}

Hanushek $(1979,1986)$ has noted that since Coleman et al. (1966) outlined "a bewildering array of technical and esoteric issues" and revealed "apparently contradictory results" on the production process of primary and secondary schools in the United States, there have been many economic studies researching the production, efficiency and cost structure of public education. The basic questions addressed in those studies are: what factors do influence students' performance? What are the determinants of educational cost structure? Are the schools operated efficiently? However, the results of these studies are surrounded by considerable 
controversy, as observed by Hanushek (1987). Researchers often find that the most excruciating part of analysis lies in the methodological issues involved.

Hanushek (1979, 1986), Woodhall (1987a,1987b), Verry (1987), and the Walberg, Cohn and Bray entries in Husen and Postlewaite (1989) provide a detailed and encyclopedic discussion of the conceptual and empirical issues commonly faced in estimating econometric models of public schools. In terms of model specification and policy focus, an earlier group of cost studies including Riew (1966), Cohn (1968, 1975), and Hough (1981) relied on a quadratic cost function in student numbers and linear in other variables (factors that might influence cost of education), with a specific focus on scale economies. This group of studies recognized the importance of other factors, but only implicitly. Except for instructional cost, other cost factors are not pursued to the extent of implicating policy issues. Jimnez (1986), alluding to the Fox (1980) review, characterized most of the previous cost studies (studies of 1960s and 1970s) as being engaged in ad hoc formulation of functional form and specification. He claimed to have specified a flexible (translog), multi-product (primary and secondary school services), quality-adjusted short run cost function based on sound economic criteria--assuming that schools are efficient and minimize cost in the short run. Jimnez used average student performance in standardized test to control for what he called students' socioeconomic backgrounds and innate abilities. However, environmental cost factors (socioeconomic characteristics of communities (SEC)) were not considered explicitly. GyimahBrempong and Gyapong (1991) used a canonical regression technique and a Cobb-Douglas production function to investigate the effects of socioeconomic characteristics (SEC) of communities as inputs in the production of high school education in Michigan. They found positive and significant impacts of SEC.

One prior study of Nebraska school districts has been published. In order to study the fiscal condition of Nebraska school districts, Ratcliffe et al. (1990) adopted the methodology of Bradbury et al. (1984). That fiscal study of Nebraska school districts examined the relationship between cost of educational services and environmental cost factors (including socioeconomic characteristics of the communities), controlling for the level 
of school output (fiscal resources and demand variables). They found five factors (handicapped students, transportation costs, proportion of elementary and secondary students, economies of scale, and interclass cost differences) which are not controllable by school officials, but do appear to have influence on the cost of public education in Nebraska. The study did not use average teacher salary or test scores as explanatory variables for

educational cost. They argued that a test score "inevitably leaves out many of the services provided by a school district." Ratcliffe et al. (1990), like Bradbury et al. (1984), presumably believed that variation in teacher salary would be reflected in the variation of environmental cost factors. In order to be comprehensive, the study claimed to have controlled for educational output (including school quality) by including variables that influence voters' decisions about school output.

\section{Frontier Approach to Estimation of Production and Cost Function of Education}

In order to examine scale economies in California public school districts, Sengupta and Sfeir (1986) estimated a nonparametric production frontier by linear programming and a parametric "average" production function by standard regression (OLS). Overall economies of scale estimated by a production frontier indicates a higher level of economies of scale for schools close to the frontier than the schools further off from the frontier. An average production function, as it is estimated by standard regression, is not susceptible to the differential scale economies across school size. Thus, Sengupta and Sfeir argued for a frontier function in capturing the differential scale effects of small and large schools. In their study, the estimated production frontier appears to have been placed neutrally downward from the average production function except for the input denoting average class size. This raises an important concern. Had the frontier not been a neutral shifting of the average function, the effect of explanatory variables estimated from the average function might not be reliable. This suggests that the importance of estimating the frontier function lies in not only efficiency analysis, but also in the need to understand the effects of individual explanatory variables when the operation of a school district is close to the frontier. 
Barrow (1991) estimated statistical one-equation stochastic cost frontier models for local educational authorities in England. While developing the model he referred to Darlington and Cullen (1984) and Levitt and Joice (1987), where the importance of socioeconomic variables had been emphasized. Barrow maintained that "the socioeconomic background variables appear to be more important statistically than variables relating to input quantities such as the pupil-teacher ratio." He used the average cost per pupil in schools as dependent variable, and the number of students as scale factor, performance in "O" level exams as output, and proportions of pupils receiving free meals, from low socioeconomic background, with additional educational needs as socioeconomic variables. He argued that socioeconomic variables could be thought of as "correcting the exam performance variables to give a measure of value added rather than gross output." It is interesting to recall that Jimnez (1986), on the contrary, used test scores to purge out the differential effects of socioeconomic background of students. Barrow's socioeconomic variables appear to have been conceived as environmental factors. To the best of our knowledge, Barrow's piece was the first published article of this type where a stochastic cost frontier was used to assess efficiency of schools. However, he did not elaborate on how the estimated cost frontier of schools could be used to guide policy analysis of fiscal issues so important for the operation of local educational authorities.

\section{Model Specification}

In case of school districts, unlike regular manufacturing plants (in technological sense, which usually operates in isolation from the community), there are compelling reasons to search for other factors that influence the cost of public education. In cost functions, disparities in local conditions have implications for spending and are characterized as uneven environmental cost factors as in Bradbury et al. (1984), community attributes as in Downes and Pogue (1994), or quasi-inputs as in Hughes (1988). This is a unique aspect of the technology involved in producing local educational services.

The distinction between a direct cost function and an indirect expenditure function, as described in Downes and Pogue (1994), is a helpful framework within which to discuss the variables that determine local 
expenditure. However, we suggest that whenever variables are put into the cost function under the umbrella of environmental factors we imply that our output measures and/or input prices are not complete. Thus, in practice, we get a quasi-cost or quasi-expenditure function. However, there is one good aspect of this incomplete output and/or input price measure. That is, we can focus on uneven environmental cost factors, and can formulate policies addressing each cost factor. Therefore, depending on the purpose of the study, availability of data, and empirical testing of the specifications, one should decide whether a quasi-cost or quasi-expenditure function would be appropriate. Given the purpose of the present paper, models of quasi-cost functions for Nebraska school districts have been formulated and estimated.

\section{Conceptual Structure for Cost Models of Nebraska School Districts}

Given the situation in Nebraska school districts, it is reasonable to assume that school districts minimize their expenditure per pupil in order to meet ever-increasing budget pressures. Assuming cost minimizing behavior by school districts and modeling inefficiency with random and systematic components, we apply the Battese and Coelli (1993) two-equation model and write the cost frontier as:

$$
\begin{aligned}
\log \left[\mathrm{DPP}_{\mathrm{i}}\right] & =\log \left[\mathrm{C}\left(\mathrm{S}_{\mathrm{i}}, \mathrm{p}_{\mathrm{i}}, \mathrm{ENF}_{\mathrm{i}}\right)\right]+v_{\mathrm{i}}+u_{\mathrm{i}} \\
u_{\mathrm{i}} & =\ddot{\mathrm{a}} \mathrm{Z}_{\mathrm{i}}+w_{\mathrm{i}} .
\end{aligned}
$$

Where $\log \left[\mathrm{DPP}_{\mathrm{i}}\right]$ is the natural logarithm of disbursement per pupil, $\mathrm{S}_{\mathrm{i}}$ is a vector of educational services, $\mathrm{p}_{\mathrm{i}}$ is a vector of input prices, and $\mathrm{ENF}_{\mathrm{i}}$ is a vector of environmental cost factors. $\mathrm{C}($.$) is the cost function and the v_{\mathrm{i}}^{\prime} \mathrm{s}$ represent a noise term assumed to be iid $\sim \mathrm{N}\left(0, \dot{o}_{v}{ }^{2}\right)$. Here, the nonnegative inefficiency effects, the $u_{\mathrm{i}}$ 's, are assumed to be independently distributed as truncated (at zero) normal distributions with constant variance ${ }^{2}{ }_{u}$ and means $\ddot{a} Z_{\mathrm{i}}$. Means are a linear function of school district specific characteristics (and time, if panel data). $Z_{\mathrm{i}}$ is a column vector of explanatory variables for inefficiency effects (including interaction between variables in the cost function and any other plausible variables; Huang and Liu, (1994)), ä is a row vector of unknown parameters, and $w_{\mathrm{i}}$ follows a truncated normal distribution (truncated at $\left.\left(-\mathrm{a} \mathrm{Z}_{\mathrm{i}}\right)\right): w_{\mathrm{i}} \sim \mathrm{N}\left(0, \dot{\mathrm{o}}_{u}{ }^{2}\right)$. The cost efficiency is defined 
as: Efficiency $=($ Actual cost/ Frontier cost $)$. This is computed as the exponential function of $\left(\ddot{a} Z_{\mathrm{i}}+w_{\mathrm{i}}\right)$. The point estimator for cost inefficiency $\left(u_{\mathrm{i}}\right)$ is the expected value of $\operatorname{EXP}\left(\ddot{a} Z_{\mathrm{i}}+w_{\mathrm{i}}\right)$, given $\left(u_{\mathrm{i}}+v_{\mathrm{i}}\right)$.

Ratcliffe et al. (1990), in the case of Nebraska school districts, and Barrow (1991) in case of cost frontier for local educational institutions, are both helpful in identifying particular variables for specification of the cost frontier for Nebraska school districts. Unlike the districts in the California system, school districts in Nebraska have control over cost per pupil. Therefore, disbursement per pupil DPP, measured as current expenditure per pupil, is an appropriate measure of educational costs in Nebraska, including instructional cost, administrative cost, transportation cost, and maintenance cost.

Enrollment and other variables have been considered as outputs (including test scores, and quality adjusting variables), as suggested by Lewis and Chakraborty (1996) and discussed in the International Encyclopedia (1989). In the cost specification for Nebraska school districts, average daily membership (ADM) is considered an output and captures the important issue of economies of sale. Graduation rates (GR) in Nebraska school districts appear to be a measure of wastage (of resources) or repetition (of students in class). It indicates a measure of the flow of students in the school districts. Since there are no standardized test scores available for Nebraska school districts, and available graduation rates are just an indication of what proportion of students fulfill the basic requirements to graduate, interpretation of graduation rates as a proxy for measure of "wastage and repetition," as suggested by Loxley (1987), seems to be helpful. In some studies, such as Jimnez (1986), standardized test scores have been used to control for students' socioeconomic backgrounds and abilities. Lewis and Chakraborty (1996) used the graduation rate as a measure of output. Ratcliffe et al. (1990) notes several studies that used test scores to adjust for the quality of students. Barrow (1991) and Downes and Pogue (1994) used test scores as measures of output.

As an input price, average salary for full time equivalent teachers (AVGS) is a standard argument in a cost function. However, some empirical studies, such as Ratcliffe et al. (1991) and Bradbury et al. (1984), have 
not used any measure of input price. They argued that not putting an input price (such as teacher salary) in the cost function would allow environmental factors to reflect both the direct effect of cost factors on expenditure and an indirect effect via input prices. It may be argued that putting input prices in the function would help to isolate the direct effect of the environmental factor on the expenditure. Moreover, it is important to remember that teacher's salary constitutes a significant portion of educational cost. There are studies, however, that include teacher salary and other composite input prices in the educational cost function: Jimnez (1986), Downes and Pogue (1994), and Lewis and Chakraborty (1996).

The proportion of special-need category students (SP), like students with limited English proficiency (LEP), is an environmental factor (ENF). This type of variable has been widely investigated in the literature. For example, Downes and Pogue (1994) examined the effects of LEP on cost per pupil in Arizona elementary and secondary public schools. Ratcliffe et al. (1990) found that in case of Nebraska school districts this variable was

important. Understanding the effects of this variable on educational expenditure has potential to provide tools for adjusting school aid formulae. ADM can be also considered as one of the environmental factors, in the sense that economies of scale contribute to the cost side of fiscal disparities, as in Ratcliffe et al. (1990).

The $\mathrm{Z}$ vector can include any variable that explains the observed cost of inefficiency. An interesting aspect of this set of variables is that it can accommodate interaction between the regular right hand side variables of the cost function and other exogenous variables. Thus, it helps to unravel any non-neutral shifting of the average response function, as described in Huang and Liu (1994). Interaction between educational experience of teachers (EDX) and the size of the school district (ADM) has been hypothesized to be a promising variable for explaining cost inefficiency for Nebraska school districts.

\section{FRONTIER MODEL ESTIMATION}

\section{Two-Equation Stochastic Cost Frontier Models}

The software package, Frontier 4.1, described in Coelli (1994), was used in this study to estimate the 
parameters of the two-equation cost frontier model and the inefficiencies of Nebraska school districts. The crucial empirical question that needs to be settled prior to embarking on the frontier cost analysis is: do we need to go beyond OLS, or is any form of stochastic cost frontier at all required? In the traditional average response function (OLS), school districts are assumed to be fully efficient, i.e., the $u_{\mathrm{i}}$ term is not present in the model. Inefficiency effects incorporated in a two-equation stochastic cost frontier model enables investigation of the causes of inefficiencies. Moreover, the capacity of such a model to accommodate interactive terms facilitates empirical testing of the OLS specification and its ability to reveal the shape of the cost frontier in the presence of inefficiency. When inefficiencies systematically affect costs, improved specification of the cost structure can be obtained using the two-equation model. The two-equation panel data model also facilitates ordering the school districts by their estimated inefficiency in each time period. This is not permitted in the one-equation frontier panel data model, as noted by Battese and Coelli $(1992,1993)$. The panel model helps us examine the dynamics of relative efficiency changes over time. Thus, the two-equation cost frontier model should provide more reliable estimates of cost structure parameters and inefficiency of the school districts.

Cross Section Models

The model for the 1989-90 and 1991-92 cross sectional data is specified as:

$$
\begin{aligned}
& \operatorname{LDPP}_{\mathrm{i}}=\hat{a}_{0}+\hat{a}_{1} \mathrm{LADM}_{\mathrm{i}}+\hat{\mathrm{a}}_{2} \mathrm{LADM}_{\mathrm{i}}^{2}+\hat{\mathrm{a}}_{3} \mathrm{LGR}_{\mathrm{i}}+\hat{a}_{4} \mathrm{LAVGS}_{\mathrm{i}}+\hat{a}_{5} \mathrm{LPSP}_{\mathrm{i}}+u_{\mathrm{i}}+v_{\mathrm{i}} \\
& u_{\mathrm{i}}=\ddot{\mathrm{a}}_{\mathrm{o}}+\ddot{\mathrm{a}}_{1}\left(\mathrm{EDX}^{*} \mathrm{LADM}\right)_{\mathrm{i}}+w_{\mathrm{i}}
\end{aligned}
$$

Variables names are as described above, with the initial letter L indicating natural logarithm, with the exception of the special needs variable SP, which has been converted into a proportion PSP. In the case of the 199091cross-section specification, however, an alternative model is used for reasons that will be explained later. Tables 1 through 6 present the results of cross section estimation.

A likelihood ratio (LR) test of the one-sided error in conjunction with the high value of ã indicates that OLS estimation is not an adequate representation of the cost structure for the Nebraska school districts observed 
over the three years. An LR test of the hypothesis that there is no systematic component in the inefficiency distribution, $\mathrm{H}_{0}$ : $\ddot{a}_{0}=\ddot{a}_{1}=0$, is rejected. An LR test for the presence of a stochastic element of inefficiency was also conducted. In order to do so, $\ddot{a}_{0}$ was set equal to zero $\left(\ddot{a}_{0}=0\right)$ and the interactive variable (EDX*LADM) was relocated from the inefficiency model to the cost function. Then the OLS regression of the cost function was run. The test statistic rejects the null hypothesis $\mathrm{H}_{0}: \tilde{\mathrm{a}}=\ddot{\mathrm{a}}_{0}=0$, and supports the existence of a stochastic element of inefficiency. The t ratio for $\hat{a}_{6}(\mathrm{EDX} * \mathrm{LADM})$ in the cost function (not reported in the table) is very low (with the asymptotic $t=-0.4649$ insignificant) indicating that inefficiency is stochastic. Thus, inefficiency consisting of systematic and stochastic components does exist $\left(\mathrm{H}_{0}: \tilde{a}=\ddot{a}_{0}=\ddot{a}_{1}=0, \mathrm{H}_{0}: \ddot{a}_{0}=\ddot{a}_{1}=0, \mathrm{H}_{0}: \tilde{a}=\ddot{a}_{0}=0\right.$, and $\mathrm{H}_{0}: \tilde{a}=$ $\ddot{a}_{1}=0$ are all rejected) in Nebraska school districts.

Except for coefficient $\hat{a} 3$, the estimated â coefficients have expected signs and are reasonably significant judging by the asymptotic $t$ ratio. Our estimated negative $\hat{a}_{1}$ and positive $\hat{a}_{2}$ coefficients reveal a concave cost function with respect to scale (ADM). Unlike the other two years, hypothesis testing for the intercept term (ä) in the inefficiency model, $\mathrm{H}_{0}: \ddot{a}_{\mathrm{o}}=0$, is rejected in 1990-91. In the inefficiency model it appears that the interactive variable $(E D X * L A D M)$ is significant by the asymptotic $t$ ratio, and has the expected negative sign. The negative sign implies that the scale efficiency is dominant over the efficiency changes associated with the relative change in educational experience of teachers. The hypothesis that the interaction between educational experience of teachers and scale of operation does not explain inefficiency $\left(\mathrm{H}_{0}: \ddot{a}_{1}=0\right)$, is also rejected by the likelihood ratio test. Thus, the inclusion of EXS (EDX*LADM) term in the inefficiency model is supported by our data. Therefore, as expected, average educational experience of teachers and scale of operation in an interactive form, $(\mathrm{EDX} * \mathrm{LADM})$ helps explain the observed inefficiencies of the schools districts.

The evidence indicated by the LR test (and also by the asymptotic $t$ ratio) that an interactive variable (EXS) can explain inefficiency, suggests a non-neutral shifting of the cost frontier with respect to educational experience of teachers and scale of operation, as described in Huang and Liu (1994). Thus, we have confirmation 
that the cost function estimated by OLS cannot even indicate the shape of the cost frontier for Nebraska school districts. The stochastic cost frontier with an explicit model of inefficiency effects emerges as a superior model.

\section{Panel Data Model}

Panel data allows incorporation of a time dimension in the cost frontier model. In terms of model structure, a two-equation panel data model is an extension of the two-equation cross section model, as described in Battese and Coelli (1993), with the inclusion of the time variable (YR) in the cost function as well as in the inefficiency model. The panel model estimated is:

$$
\begin{aligned}
& \mathrm{LDPP}_{\mathrm{it}}=\hat{\mathrm{a}}_{0}+\hat{\mathrm{a}}_{1} \mathrm{LADM}_{\mathrm{it}}+\hat{\mathrm{a}}_{2} \mathrm{LADM}_{\mathrm{it}}{ }^{2}+\hat{\mathrm{a}}_{3} \mathrm{LGR}_{\mathrm{it}}+\hat{\mathrm{a}}_{4} \mathrm{LAVGS}_{\mathrm{it}}+\hat{\mathrm{a}}_{5} \mathrm{LPSP}_{\mathrm{it}}+\hat{\mathrm{a}}_{6} \mathrm{YR}_{\mathrm{it}}+\mathrm{u}_{\mathrm{it}}+v_{\mathrm{it}}(5 \mathrm{a}) \\
& u_{\mathrm{it}}=\ddot{\mathrm{a}}_{\mathrm{o}}+\ddot{\mathrm{a}}_{1} \mathrm{LEDX}_{\mathrm{it}}+\ddot{\mathrm{a}}_{2} \mathrm{LADM}_{\mathrm{it}}+\ddot{\mathrm{a}}_{3} \mathrm{YR}_{\mathrm{it}}+w_{\mathrm{it}}, \mathrm{t}=1,2, \& 3 \text { years. }
\end{aligned}
$$

Results are presented in Tables 7 and 8. With panel data, the hypothesis, $H_{0}: \tilde{a}=0$ is overwhelmingly rejected. Thus, as in the cross section models, the panel data model does not suggest OLS estimation of the cost function to be appropriate for the data. Testing for stochastic inefficiency effects indicates that the effects are $\operatorname{random}\left(\mathrm{H}_{0}: \tilde{\mathrm{a}}=\ddot{\mathrm{a}}_{0}=\ddot{\mathrm{a}}_{2}=\ddot{\mathrm{a}}_{3}=0\right.$, is rejected). As inefficiency exists, and is stochastic in nature, the inclusion of a time variable both in the cost frontier function and the inefficiency effects model is permissible.

Estimation results of the model indicate that with the exception of LGR and YR variables in the cost frontier function, all the â coefficients are significant judging by the asymptotic $t$ ratios. Signs for $\hat{a}_{1}$ through $\hat{a}_{5}$ are consistent with those of the cross section models. The absolute value of the estimated coefficient for the variable graduation rate is similar to that of the $1989-90$ cross section model. The value of the coefficient for the average teacher salary variable is estimated to be very close to that of the 1991-92 cross section model. The intercept $\hat{a}_{o}$ in the panel data model is estimated to be in the vicinity of the 1990-91 and 1991-92 estimates, but higher than that of the 1989-90 cross section model. Estimated values of the other â coefficients are similar to those of the cross section models.

The positive coefficient for the year variable $\left(\hat{a}_{6}\right)$ in the cost frontier function implies that the cost 
frontiers move up over time. Since all the input prices are not held constant in the model, a positive â6 might also reflect increasing input prices. Thus, it is consistent with the general concern that there is an increasing trend of the cost of education in Nebraska school districts. It is possible that the time variable (YR) might also pick up other effects, such as reforms in the funding and distribution of state aid to school districts in Nebraska.

In the efficiency model, the LEDX variable appears to be highly significant, but the YR and LADM variables are not. As expected, signs of the explanatory variables in the inefficiency model are negative. A negative coefficient for the time (YR) variable in the inefficiency model indicates that individual school districts are catching up with their corresponding frontier values. This is certainly a desirable outcome. However, a regressive technological change indicated by the positive coefficient of the time variable (YR) in the cost frontier, should be a serious concern for policy makers. Teachers' educational experience and larger scale school operation appear to have positive effects on the cost efficiency of school districts. Scale efficiency was also observed in the case of cross section data. Hypothesis tests for $\hat{a}_{6}(\mathrm{YR})=0$ and $\ddot{a}_{3}(\mathrm{YR})=0$ are both rejected, and $\ddot{a}_{1}(\mathrm{LEDX})=0$, is rejected too, while the hypothesis $\mathrm{H}_{0}: \ddot{\mathrm{a}}_{0}=0$ is accepted. Results of hypotheses testing are presented in Table 8.

It is interesting to note that contrary to the cross section models, the panel data model does not support the idea that the multiplicative interaction between LADM and EDX (or LEDX) would explain the inefficiency effects. In the model for explaining inefficiency we have LEDX, LADM, and YR variables. No interaction between scale of operation and other variables has been accommodated in an explicit way. Hypothesis testing for the interaction term, ((EDX*LADM) or (LEDX*LADM)), does not support their inclusion in the model. Interactive terms like, EDX*LADM or LEDX*LADM, do not appear to be good explanatory variables for the inefficiency model. However, in the panel model we can see that the interaction between educational experience of teachers (EDX) and scale of operation (ADM) has been taken into account in an implicit way. The form of interaction $(\log (\mathrm{EDX} * \mathrm{ADM})=\log \mathrm{EDX}+\log \mathrm{ADM}=\mathrm{LEDX}+\mathrm{LADM})$ is different than that in the cross 
section models. Thus, the panel data model also indicates that the inefficiency effects cause a non-neutral shifting of the cost frontier.

Since the panel data are for three years only, it is not surprising that the educational experience of teachers would explain the larger part of the inefficiency in school operation than the time variable (YR) does. However, inclusion of the time variable in the inefficiency model does provide insights into the dynamics of the relative change in the efficiencies of the school districts over time.

\section{USE OF COST FRONTIER ANALYSIS}

\section{Rankings of School Districts by Efficiency Estimates}

Based on the preferred cross section model for each of the three years, cost efficiency of each of the 274 Nebraska school districts was estimated. School districts were arranged in a descending order of their estimated inefficiency (higher rank indicates a higher level of efficiency). We observe that school districts rated most inefficient at one point of time do not always remain so during the three years of this study. For example, Santee Public Schools was the most inefficient school district in 1989-90, but in 1990-91 it improved its position to the fifth rank and maintained that ranking through 1991-92. Some school districts have exhibited tremendous improvement in terms of cost efficiency. Loup County Public Schools was in fifth position in 1989-90, and then improved to eighteenth position in 1990-91, and then improved further to the sixtieth position in 1991-92. We find that from 65 to 82 percent of Nebraska school districts fall in the range of 10 percent or less inefficiency (65.69 percent in 1989-90, 78.46 percent in 1990-91, 81.28 percent in 1991-92). The number of schools with inefficiency of more than 10 percent declined over the years of our study (34.31 percent, 21.54 percent, 18.72 percent). In addition, the percentage of districts with more than 15 percent inefficiency declined by about 50 percent over the three year period (17.53 percent, 10.60 percent and 8.51 percent).

Improvement over time in the cost efficiency of the school districts is clearly evident. The number of districts with more than 10 percent inefficiency diminished over the years. For the years 1989-90 and 1991-92, 
the mode of the distribution was not in the most efficient range (1.05). This observation provides ex post evidence supporting our assumption of a general truncated distribution for inefficiencies. Here, it is important to note that the built-in distributional assumption of the two-equation model conforms to the observed empirical results. However, this is not evident in the case of the 1990-91 efficiency distribution.

Efficiencies of the 274 school districts were also estimated using the two-equation panel data model and arranged in a descending order. Estimates of inefficiency by the panel data model appeared to be higher than those estimated by the cross section models. In the inefficiency range of beyond 10 percent, there were 33.59 percent, 27.65 percent, and 24.83 percent school districts in 1989-90,1990-91 and 1991-92 respectively. Evidently, there has been a trend of improvement in terms of cost efficiency of school districts. In fact, this is consistent with the negative coefficient of the time (YR) variable appeared in the inefficiency effect model of the cost frontier. This trend was also noticed with the pooled cost efficiencies estimated by the three cross section models. Thus, the cost frontier estimation reveals the dynamics of change in school efficiencies. Spearman rank correlation coefficients presented in Table 9 indicates a close association between the cross section and panel data correlations for a given year. However, a less clear association between the rankings by either model is observed when there is more time difference.

\section{Aid Formula Implications for Nebraska School Districts}

Bradbury et al. (1984) calculated the cost index for each of the local jurisdictions in their Massachusetts study. In order to calculate the cost index, their method was to predict "what each community would have spent if it had average resources, average demand and average population change, but retained its own values for the cost variables." Then the predicted expenditures were divided by the mean per capita expenditure for all 351 cities and towns in Massachusetts. An index value above one indicated extra cost incurred for adverse environmental cost factors specific to that community. It is obvious in this case, however, that the cost index calculated by Bradbury et al. (1984) is based on an average community. 
The cost function frontier approach can help reduce fiscal disparities in two ways. One way is to adjust the cost index calculated for a local jurisdiction by its efficiency estimates. For example, as indicated by Bradbury et al. (1984), in Boston there was 40 percent more expenditure per person compared to a community with average characteristics. Now, if it is known that the cost efficiency index for Boston municipal services is, say, 1.3, then it is fair to suggest that the intergovernmental aid associated with Boston's cost index of 1.4 must be scaled down by its cost inefficiency of 30 percent.

Ratcliffe et al. (1990) combined the five cost factors, "that are largely outside the control of school officials and that influence the cost of public education in Nebraska" into a single cost index for each school district in the state. As explained above, the cost indices for Nebraska school districts can now be adjusted using the estimated cost efficiencies and may then be used in the school aid formula used for offsetting the fiscal disparities among Nebraska school districts. This adjustment would help impose financial and operational discipline on the school districts.

The other way in which the efficiency estimates can be used to reduce fiscal disparities is to incorporate the efficiency factor directly into the intergovernmental aid formula. This approach is obviously not dependent on an average school district concept. It assumes that we can calculate the most efficient cost level for the operation of a particular school district on the basis of that district's inefficiency quotient. The most efficient cost level calculated on the basis of a stochastic cost frontier is unique for a particular school district. Thus, there is no need to compare with an average school district. An additional advantage is that it allows considering all of the factors in their unique value for that school district. Thus, the judgmental issue as to which factors to include as the environmental cost factors and which to retain at their average value, as in Bradbury et al. (1984) footnote 10, can be avoided.

The results of the computation presented below in Table 10 illustrate the idea. The intergovernmental aid formula can make an attempt to offset the fiscal disparity by focusing on the frontier cost rather than on 
actual cost. Calculation of frontier cost has taken into account the systematic adverse factors. Moreover, it has accounted for any random unfavorable or favorable conditions. It is often argued that in order to avoid encouraging inefficiency intergovernmental aid should not compensate for controllable factors. By the same token, intergovernmental aid should not compensate for inefficient operation of school districts. As we know, for example, the Hayes Center public school district spends an extra $\$ 1320.35 /$ pupil due to inefficient operation. This knowledge could help to save a quarter of a million dollars per year $(\$ 236,871$ year) in intergovernmental aid. Similar calculations show inefficiency costs of \$5.56 million/year for the Omaha public schools and \$4.31 million/year for the Lincoln public schools. For Keamey and Chadron public schools the cost of inefficiency amounts to $\$ 0.43$ million and $\$ 0.15$ million per year respectively.

Splitting the composite error term into its constituent pieces reveals information about the random favorable and unfavorable condition in which school districts operate. This information has obvious bearing on the designing of state aid formulae for school districts. The following will explain the procedure of estimating the dollar value of the random favorable or unfavorable condition. The term $f\left(y_{i}, p_{i}, E N F_{i}, \hat{a}\right)$ can be obtained by inserting the actual value of the arguments $\left(\mathrm{y}_{\mathrm{i}}, \mathrm{p}_{\mathrm{i}}, \mathrm{ENF}_{\mathrm{i}}\right)$ in the estimated regression function. Thus, $\exp \left(v_{\mathrm{i}}\right)$ can be calculated, from which the cost or benefit for the unfavorable or favorable condition respectively can be estimated. As examples, the results of this calculation for selected Nebraska school districts are presented in Table 11. Such information for each school district can be utilized for adjusting the school aid formula, which would help minimize the state aid cost. Moreover, this would help modify the approach presently taken to mitigate the fiscal disparities among Nebraska school districts.

\section{Summary and Conclusions}

In this paper, we have proposed the use of a two-equation stochastic frontier model for the estimation of school district cost and have estimated such models using both cross section and panel data for Nebraska school districts. Our results indicate that stochastic frontier models can contribute a great 
deal of insight regarding school district cost and sources of inefficiency. First, the usual OLS method of estimation is clearly rejected with a stochastic frontier model being clearly superior. Based on both our cross section and panel data estimations, there are scale economies apparent in school district cost. The cost frontier declines with school district membership and is concave. Furthermore, teachers' educational experience appears to exert a positive effect on cost efficiency of school districts. A large part of the estimated inefficiency across school districts is explained by differences in teacher experience. In the cross section models, the interaction between district membership and teacher experience helps explain the observed inefficiencies of the school districts. The panel data models also indicate that the inefficiency effects cause a non-neutral shifting of school district cost functions. The form of interaction is different than that in the cross section models, however. Teacher educational experience and larger scale both have positive effects on the cost effectiveness of districts.

Estimated sources of inefficiency are then very useful in helping to determine district need for the purpose of computing state aid. We are able to construct indices of school district efficiency based on our models. Then, we can use the models to estimate the cost frontier for districts, reflecting the least cost attainable, given the experience of districts in the sample. Based on that computation, we can then compute an adjusted measure of need for the purpose of computing state aid. Rather than defining need on the basis of average cost, as would be the case using a conventional regression model, we can define need with reference to the cost frontier, taking into account favorable and unfavorable conditions in school districts. Such an application clearly demonstrates the very useful potential of these methods. 
Figure 1: Cost Frontier Illustration

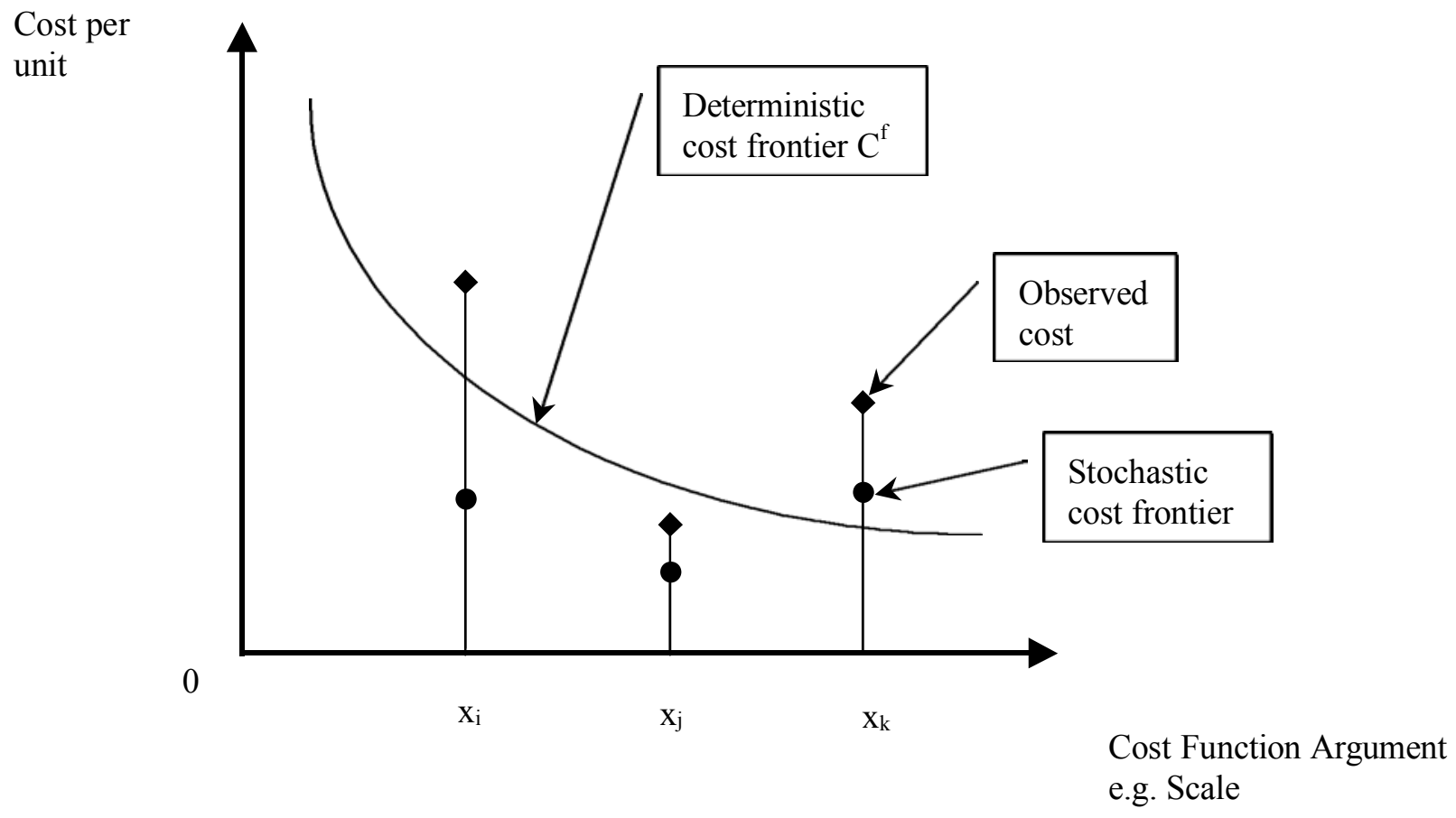


Table 1: Maximum-Likelihood Estimates of Parameters of Stochastic Cost Frontier and Inefficiency Models for Nebraska School Districts in 1989-90 (Cross Section Models)

\begin{tabular}{|c|c|c|c|c|}
\hline Variable & Parameter & $\begin{array}{l}\text { General } \\
\text { Model }\end{array}$ & $\begin{array}{l}\text { Preferred } \\
\text { Model }\end{array}$ & OLS \\
\hline \multicolumn{5}{|c|}{ Stochastic Cost Frontier } \\
\hline Constant & $\beta_{0}$ & $\begin{array}{l}1.069 \\
(1.137)\end{array}$ & $\begin{array}{l}2.077 \\
(2.52)\end{array}$ & $\begin{array}{l}3.746 \\
(3.83)\end{array}$ \\
\hline $\log (\mathrm{ADM})$ & $\beta_{1}$ & $\begin{array}{l}-0.9103 \\
(-16.768)\end{array}$ & $\begin{array}{l}-0.9401 \\
(-17.75)\end{array}$ & $\begin{array}{l}-1.039 \\
(-16.68)\end{array}$ \\
\hline$[\log (\mathrm{ADM})]^{2}$ & $\beta_{2}$ & $\begin{array}{l}0.0538 \\
(14.143)\end{array}$ & $\begin{array}{l}0.0558 \\
(15.04)\end{array}$ & $\begin{array}{l}0.0625 \\
(13.88)\end{array}$ \\
\hline $\log (\mathrm{GR})$ & $\beta_{3}$ & $\begin{array}{l}0.0389 \\
(0.998)\end{array}$ & $\begin{array}{l}0.0299 \\
(0.7300)\end{array}$ & $\begin{array}{l}0.0697 \\
(1.54)\end{array}$ \\
\hline $\log (\mathrm{AVGS})$ & $\beta_{4}$ & $\begin{array}{l}1.047 \\
(11.22)\end{array}$ & $\begin{array}{l}0.9588 \\
(11.41)\end{array}$ & $\begin{array}{l}0.8162 \\
(8.12)\end{array}$ \\
\hline $\log (\mathrm{PSP})$ & $\beta_{5}$ & $\begin{array}{l}0.0373 \\
(1.742)\end{array}$ & $\begin{array}{l}0.0443 \\
(2.09)\end{array}$ & $\begin{array}{l}0.0541 \\
(2.45)\end{array}$ \\
\hline \multicolumn{5}{|c|}{ Inefficiency Model } \\
\hline Constant & $\ddot{a}_{0}$ & $\begin{array}{l}0.8230 \\
(2.877)\end{array}$ & 0 & --- \\
\hline $\mathrm{EDX} * \log (\mathrm{ADM})$ & $\ddot{a}_{1}$ & $\begin{array}{l}-0.0206 \\
(-2.243)\end{array}$ & $\begin{array}{l}-0.0245 \\
(-2.10)\end{array}$ & --- \\
\hline \multirow[t]{2}{*}{ Variance Parameters } & $\dot{o}^{2}=\dot{o}^{2}{ }_{\mathrm{u}}+\dot{o}_{\mathrm{v}}^{2}$ & $\begin{array}{l}0.0812 \\
(3.28)\end{array}$ & $\begin{array}{l}0.2002 \\
(2.67)\end{array}$ & 0.0159 \\
\hline & $=\frac{\frac{2}{u}}{{ }_{u}^{2}+{ }_{v}^{2}}$ & $\begin{array}{l}0.9065 \\
(30.97)\end{array}$ & $\begin{array}{l}0.9680 \\
(83.33)\end{array}$ & 0 \\
\hline Log-Likelihood Function & & 203.16 & 202.04 & 181.07 \\
\hline $\begin{array}{l}* \text { LR test of the one-sided } \\
\text { error }\left(\mathrm{H}_{0}: \tilde{\mathrm{a}}=0\right)\end{array}$ & & 44.18 & 41.94 & --- \\
\hline With number of restrictions & & 3 & 2 & --- \\
\hline
\end{tabular}

Estimated asymptotic $t$ ratios are given in parentheses below the parameter estimates.

Level of significance $=5 \%$,

* Likelihood ratio test (LR). 
Table 2: Generalized-Likelihood Ratio Tests of Hypotheses for Nebraska School Districts in 1989-90 (Cross Section Models)

\begin{tabular}{lllll}
\hline & \multicolumn{4}{l}{ Hypothesis Testing with Reference to the General Model } \\
\hline Null Hypotheses & Log-Likelihood & $\dot{\div}^{2}$ Statistic & Critical Value & Decision \\
$\mathrm{H}_{0}: \tilde{\mathrm{a}}=\ddot{\mathrm{a}}_{0}=\ddot{\mathrm{a}}_{1}=0$ & 181.07 & 44.18 & 7.82 & Reject $\mathrm{H}_{0}$ \\
$\mathrm{H}_{0}: \tilde{\mathrm{a}}=\ddot{\mathrm{a}}_{0}=0$ & 181.46 & 43.40 & 5.99 & Reject $\mathrm{H}_{0}$ \\
$\mathrm{H}_{0}: \ddot{\mathrm{a}}_{0}=0$ & 202.04 & 2.24 & 3.84 & Accept $\mathrm{H}_{0}$ \\
$\mathrm{H}_{0}: \ddot{\mathrm{a}}_{1}=0$ & 196.12 & 14.08 & 3.84 & Reject $\mathrm{H}_{0}$ \\
$\mathrm{H}_{0}: \ddot{\mathrm{a}}_{0}=\ddot{a}_{1}=0$ & 192.35 & 21.62 & 5.99 & Reject $\mathrm{H}_{0}$ \\
$\left(\mathrm{Given}\right.$ Restriction: $\left.\ddot{a}_{0}=0\right)$ & Hypothesis Testing with Reference to the Preferred Model \\
$\mathrm{H}_{0}: \tilde{\mathrm{a}}=\ddot{\mathrm{a}}_{1}=0$ & 181.07 & 41.94 & 5.99 & Reject $\mathrm{H}_{0}$ \\
$\mathrm{H}_{0}: \ddot{\mathrm{a}}_{1}=0$ & 192.35 & 19.38 & 3.84 & Reject $\mathrm{H}_{0}$ \\
$\mathrm{H}_{0}: \tilde{\mathrm{a}}=0$ & 181.46 & 41.16 & 3.84 & Reject $\mathrm{H}_{0}$ \\
\hline
\end{tabular}

Level of significance $=5 \%$. 
Table 3: Maximum-Likelihood Estimates of Parameters of Stochastic Cost Frontier and Inefficiency Models for Nebraska School Districts in 1990-91 (Cross Section Models)

\begin{tabular}{|c|c|c|c|c|c|}
\hline \multirow[t]{2}{*}{ Variable } & \multicolumn{2}{|c|}{ Parameter } & $\begin{array}{l}\text { Alternative } \\
\text { Model }\end{array}$ & $\begin{array}{l}\text { Preferred } \\
\text { Model }\end{array}$ & \multirow[t]{2}{*}{ OLS } \\
\hline & \multicolumn{4}{|c|}{ Stochastic Cost Frontier } & \\
\hline Constant & \multicolumn{2}{|l|}{$\beta_{0}$} & $\begin{array}{l}3.38 \\
(3.18)\end{array}$ & $\begin{array}{l}3.09 \\
(2.90)\end{array}$ & $\begin{array}{l}5.87 \\
(6.01)\end{array}$ \\
\hline $\log (\mathrm{ADM})$ & \multicolumn{2}{|l|}{$\beta_{1}$} & $\begin{array}{l}-0.8372 \\
(-3.42)\end{array}$ & $\begin{array}{l}-0.9252 \\
(-16.43)\end{array}$ & $\begin{array}{l}-1.017 \\
(-18.20)\end{array}$ \\
\hline$[\log (\mathrm{ADM})]^{2}$ & \multicolumn{2}{|l|}{$\beta_{2}$} & $\begin{array}{l}0.0496 \\
(3.31)\end{array}$ & $\begin{array}{l}0.0549 \\
(14.00)\end{array}$ & $\begin{array}{l}0.0611 \\
(14.99)\end{array}$ \\
\hline $\log (\mathrm{GR})$ & \multicolumn{2}{|l|}{$\beta_{3}$} & $\begin{array}{l}-0.2643 \\
(-2.45)\end{array}$ & $\begin{array}{l}-0.2493 \\
(-2.40)\end{array}$ & $\begin{array}{l}-0.3441 \\
(-3.42)\end{array}$ \\
\hline Log (AVGS) & \multicolumn{2}{|l|}{$\beta_{4}$} & $\begin{array}{l}0.9225 \\
(7.68)\end{array}$ & $\begin{array}{l}0.9791 \\
(10.61)\end{array}$ & $\begin{array}{l}0.7846 \\
(8.47)\end{array}$ \\
\hline \multirow[t]{2}{*}{$\log (\mathrm{PSP})$} & \multicolumn{2}{|l|}{$\beta_{5}$} & $\begin{array}{l}0.0555 \\
(2.72)\end{array}$ & $\begin{array}{l}0.0560 \\
(2.93)\end{array}$ & $\begin{array}{l}0.0577 \\
(3.07)\end{array}$ \\
\hline & \multicolumn{4}{|c|}{ Inefficiency Model } & \\
\hline Constant & \multicolumn{2}{|l|}{$\delta_{0}$} & $\begin{array}{l}1.46 \\
(2.00)\end{array}$ & $\begin{array}{l}0.6669 \\
(2.47)\end{array}$ & --- \\
\hline $\mathrm{EDX} * \log (\mathrm{ADM})$ & \multicolumn{2}{|l|}{$\delta_{1}$} & --- & $\begin{array}{l}-0.0162 \\
(-1.65)\end{array}$ & --- \\
\hline EDX & \multicolumn{2}{|l|}{$\delta_{2}$} & $\begin{array}{l}-0.0296 \\
(-0.4536)\end{array}$ & --- & --- \\
\hline $\log (\mathrm{ADM})$ & \multicolumn{2}{|l|}{$\delta_{3}$} & $\begin{array}{l}-0.2187 \\
(-1.98)\end{array}$ & --- & --- \\
\hline \multirow[t]{2}{*}{ Variance Parameters } & ${ }^{2}=$ & ${ }_{u}^{2}+{ }_{v}^{2}$ & $\begin{array}{l}0.0357 \\
(0.7430)\end{array}$ & $\begin{array}{l}0.0582 \\
(1.88)\end{array}$ & 0.0138 \\
\hline & \multicolumn{2}{|c|}{$=\frac{\frac{2}{u}}{{ }_{u}^{2}+{ }_{v}^{2}}$} & $\begin{array}{l}0.8049 \\
(3.40)\end{array}$ & $\begin{array}{l}0.8649 \\
(9.76)\end{array}$ & 0 \\
\hline \multicolumn{3}{|c|}{ Log-Likelihood Function } & 212.37 & 212.74 & 200.18 \\
\hline \multicolumn{3}{|c|}{$\begin{array}{l}* \text { LR test of the one-sided } \\
\text { error }\left(\mathrm{H}_{0}: \tilde{a}=0\right)\end{array}$} & 24.38 & 25.11 & --- \\
\hline \multicolumn{3}{|c|}{ With number of restrictions } & 4 & 3 & --- \\
\hline
\end{tabular}

Estimated asymptotic $\mathrm{t}$ ratios are given in parenthesis below the parameter estimates. Level of significance $=5 \%$.

* Likelihood ratio test (LR). 
Table 4: Generalized-Likelihood Ratio Tests of Hypotheses for Nebraska School Districts in 1990-91 (Cross Section Models)

\begin{tabular}{lllll}
\hline & \multicolumn{4}{l}{ Hypothesis Testing with Reference to the Preferred Model } \\
\hline Null Hypotheses & Log-Likelihood & $\dot{\div}^{2}$ Statistic & Critical Value & Decision \\
$\mathrm{H}_{0}: \tilde{\mathrm{a}}=\ddot{\mathrm{a}}_{0}=\ddot{\mathrm{a}}_{1}=0$ & 200.18 & 25.11 & 7.82 & Reject $\mathrm{H}_{0}$ \\
$\mathrm{H}_{0}: \tilde{\mathrm{a}}=\ddot{\mathrm{a}}_{0}=0$ & 200.92 & 23.64 & 5.99 & Reject $\mathrm{H}_{0}$ \\
$\mathrm{H}_{0}: \ddot{\mathrm{a}}_{0}=\ddot{\mathrm{a}}_{1}=0$ & 205.54 & 14.40 & 5.99 & Reject $\mathrm{H}_{0}$ \\
$\mathrm{H}_{0}: \ddot{\mathrm{a}}_{1}=0$ & 206.78 & 11.92 & 3.84 & Reject $\mathrm{H}_{0}$ \\
$\mathrm{H}_{0}: \ddot{\mathrm{a}}_{0}=0$ & 211.28 & 2.92 & 3.84 & Accept $\mathrm{H}_{0}$ \\
& & & \\
& Hypotheses Testing with Reference to the Alternative Model & \\
$\mathrm{H}_{0}: \ddot{\mathrm{a}}_{3}=0$ & 211.66 & 1.42 & 3.84 & Accept $\mathrm{H}_{0}$ \\
\hline
\end{tabular}
Level of significance $=5 \%$. 
Table 5: Maximum-Likelihood Estimates of Parameters of Stochastic Cost Frontier and Inefficiency Models for Nebraska School Districts in 1991-92 (Cross Section Models)

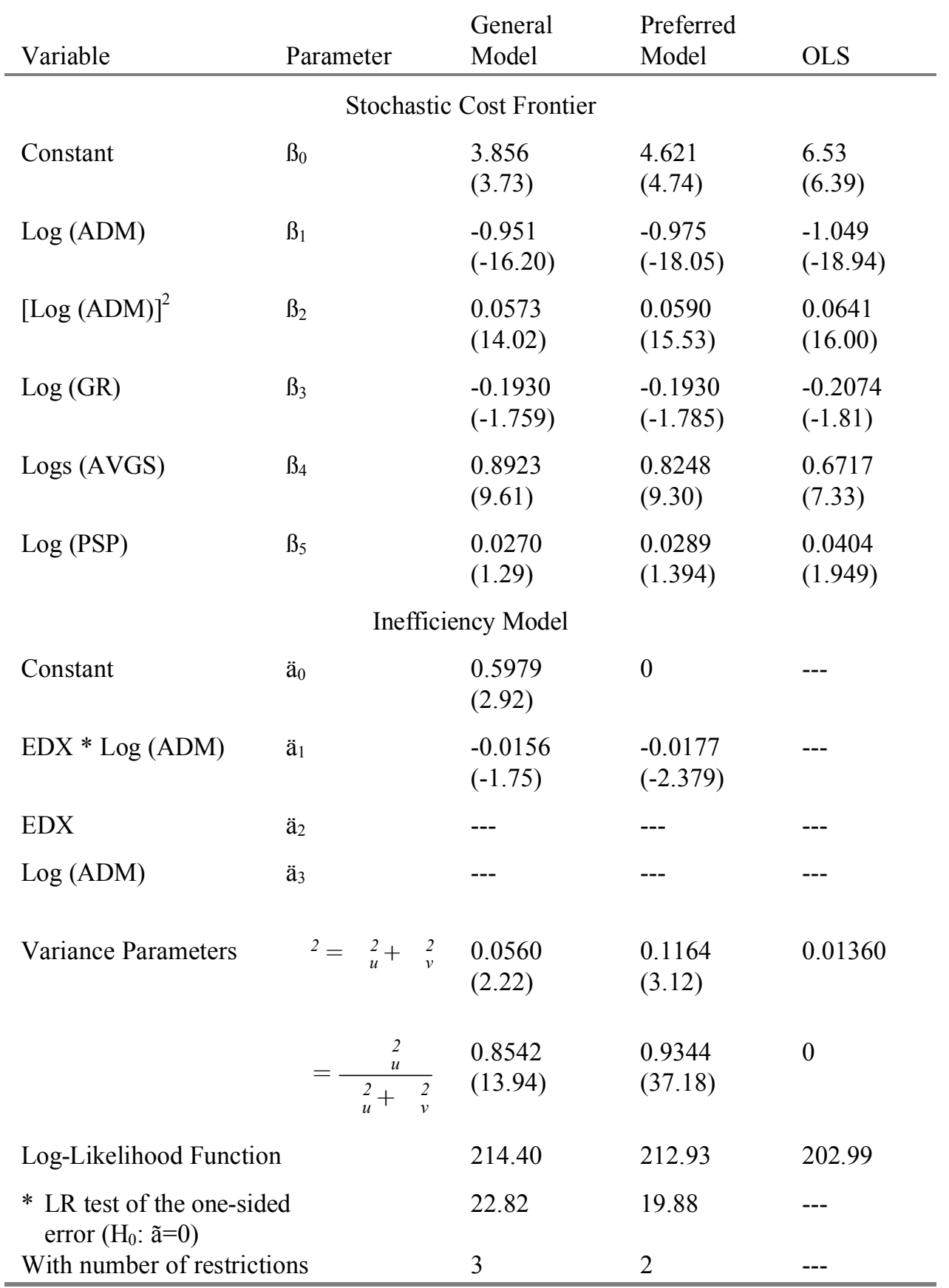

Estimated asymptotic $t$ ratios are given in parenthesis below the parameter estimates. Level of significance $=5 \%$.

*Likelihood ratio test (LR). 
Table 6: Generalized-Likelihood Ratio Tests of Hypotheses for Nebraska School Districts in 1991-92 (Cross Section Models)

\begin{tabular}{lllll}
\hline & \multicolumn{4}{l}{ Hypothesis Testing with Reference to the General Model } \\
\hline Null Hypotheses & Log-Likelihood & $\dot{\div}^{2}$ Statistic & Critical Value & Decision \\
$\mathrm{H}_{0}: \tilde{\mathrm{a}}=\ddot{\mathrm{a}}_{0}=\ddot{\mathrm{a}}_{1}=0$ & 202.99 & 22.82 & 7.82 & Reject $\mathrm{H}_{0}$ \\
$\mathrm{H}_{0}: \tilde{\mathrm{a}}=\ddot{\mathrm{a}}_{0}=0$ & 203.02 & 22.76 & 5.99 & Reject $\mathrm{H}_{0}$ \\
$\mathrm{H}_{0}: \ddot{\mathrm{a}}_{0}=0$ & 212.93 & 2.94 & 3.84 & Accept $\mathrm{H}_{0}$ \\
$\left(\right.$ Given Restriction: $\left.\ddot{a}_{0}=0\right)$ & Hypotheses Testing With Reference to the Preferred Model \\
$\mathrm{H}_{0}: \ddot{\mathrm{a}}_{1}=0$ & 205.84 & 14.18 & 3.84 & Reject $\mathrm{H}_{0}$ \\
\hline
\end{tabular}

Level of significance $=5 \%$. 
Table 7: Maximum-Likelihood Estimates of Parameters of Stochastic Cost Frontier and Inefficiency Models for Nebraska School Districts in 1989-90 Through 1991-92 (Panel Data Models)

\begin{tabular}{|c|c|c|c|c|}
\hline Variable & Parameter & $\begin{array}{l}\text { General } \\
\text { Model }\end{array}$ & $\begin{array}{l}\text { Preferred } \\
\text { Model }\end{array}$ & OLS \\
\hline \multicolumn{5}{|c|}{ Stochastic Cost Frontier } \\
\hline Constant & $\beta_{0}$ & $\begin{array}{l}3.64 \\
(6.51)\end{array}$ & $\begin{array}{l}3.77 \\
(6.47\end{array}$ & $\begin{array}{l}5.13 \\
(4.18)\end{array}$ \\
\hline $\log (\mathrm{ADM})$ & $\beta_{1}$ & $\begin{array}{l}-1.004 \\
(-26.08)\end{array}$ & $\begin{array}{l}-0.9853 \\
(-26.16)\end{array}$ & $\begin{array}{l}-1.0164 \\
(-13.29)\end{array}$ \\
\hline$[\log (\mathrm{ADM})]^{2}$ & $\beta_{2}$ & $\begin{array}{l}0.0603 \\
(22.06)\end{array}$ & $\begin{array}{l}0.0593 \\
(22.03)\end{array}$ & $\begin{array}{l}0.0621 \\
(11.20)\end{array}$ \\
\hline $\log (\mathrm{GR})$ & $\beta_{3}$ & $\begin{array}{l}-0.0159 \\
(-0.3674)\end{array}$ & $\begin{array}{l}-0.0246 \\
(-0.5814)\end{array}$ & $\begin{array}{l}0.0215 \\
(0.255)\end{array}$ \\
\hline Logs (AVGS) & $\beta_{4}$ & $\begin{array}{l}0.8403 \\
(14.54)\end{array}$ & $\begin{array}{l}0.8237 \\
(13.47)\end{array}$ & $\begin{array}{l}0.6853 \\
(5.47)\end{array}$ \\
\hline $\log (\mathrm{PSP})$ & $\beta_{5}$ & $\begin{array}{l}0.0452 \\
(3.02)\end{array}$ & $\begin{array}{l}0.0448 \\
(2.98)\end{array}$ & $\begin{array}{l}0.0397 \\
(1.46)\end{array}$ \\
\hline YR & $\beta_{6}$ & $\begin{array}{l}0.0128 \\
(1.84)\end{array}$ & $\begin{array}{l}0.0105 \\
(1.68)\end{array}$ & $\begin{array}{l}-0.0081 \\
(-0.6785)\end{array}$ \\
\hline \multicolumn{5}{|c|}{ Inefficiency Model } \\
\hline Constant & $\ddot{a}_{0}$ & $\begin{array}{l}-3.28 \\
(-2.45)\end{array}$ & 0 & --- \\
\hline $\log (\mathrm{EDX})$ & $\ddot{a}_{1}$ & $\begin{array}{l}-0.2287 \\
(-0.5645)\end{array}$ & $\begin{array}{l}-1.454 \\
(-8.48)\end{array}$ & --- \\
\hline $\log (\mathrm{ADM})$ & $\ddot{a}_{2}$ & $\begin{array}{l}0.01233 \\
(0.4430)\end{array}$ & $\begin{array}{l}-0.0414 \\
(-0.7595)\end{array}$ & --- \\
\hline YR & $\ddot{a}_{3}$ & $\begin{array}{l}-0.3909 \\
(-8.64)\end{array}$ & $\begin{array}{l}-0.2528 \\
(-1.85)\end{array}$ & --- \\
\hline \multirow[t]{2}{*}{ Variance Parameters } & $\sigma^{2}{ }_{u}=\sigma^{2}{ }_{u}+\sigma^{2}{ }_{v}$ & $\begin{array}{l}0.3873 \\
(16.23)\end{array}$ & $\begin{array}{l}0.4311 \\
(19.41)\end{array}$ & 0.0761 \\
\hline & $=\frac{\frac{2}{u}}{{ }_{u}^{2}+{ }_{v}^{2}}$ & $\begin{array}{l}0.9769 \\
(567.06)\end{array}$ & $\begin{array}{l}0.9807 \\
(482.95)\end{array}$ & 0 \\
\hline \multicolumn{2}{|c|}{ Log-Likelihood Function } & 593.38 & 593.13 & -104.37 \\
\hline \multicolumn{2}{|c|}{$\begin{array}{l}* \text { LR test of the one-sided } \\
\text { error }\left(\mathrm{H}_{0}: \tilde{\mathrm{a}}=0\right)\end{array}$} & $\begin{array}{l}1395.51 \\
\text { Rest }=5 \\
51\end{array}$ & $\begin{array}{l}1395.03 \\
\text { Rest }=4 \\
100\end{array}$ & $\begin{array}{l}--- \\
---\end{array}$ \\
\hline
\end{tabular}

Estimated asymptotic $\mathrm{t}$ ratios are given in parenthesis below the parameter estimates.

Level of significance $=5 \%$.

* Likelihood ratio test (LR). 
Table 8: Generalized-Likelihood Ratio Tests of Hypotheses for Nebraska School Districts in 1989-90 to 1991-92 (Panel Data Models).

\begin{tabular}{lllll}
\hline & \multicolumn{4}{l}{ Hypothesis Testing with Reference to the General Model } \\
\hline Null Hypotheses & Log-Likelihood Value & $\dot{\div}^{2}$ Statistic & Critical Value & Decision \\
$\mathrm{H}_{\mathrm{o}}: \tilde{\mathrm{a}}=\ddot{\mathrm{a}}_{0}=\ddot{\mathrm{a}}_{1}=\ddot{\mathrm{a}}_{2}=\ddot{\mathrm{a}}_{3}=\mathrm{o}$ & -104.37 & 1395.51 & 11.07 & Reject Ho \\
$\mathrm{H}_{\mathrm{o}}: \ddot{\mathrm{a}}_{0}=0$ & 593.13 & 0.50 & 3.84 & Accept $\mathrm{H}_{\mathrm{o}}$ \\
$\mathrm{H}_{\mathrm{o}}: \tilde{\mathrm{a}}=\ddot{\mathrm{a}}_{0}=\ddot{\mathrm{a}}_{2}=\ddot{\mathrm{a}}_{3}=0$ & -102.63 & 1392.02 & 9.49 & Reject $\mathrm{H}_{\mathrm{o}}$ \\
$\left(\right.$ Given Restriction: $\left.\ddot{\mathrm{a}}_{0}=0\right)$ & Hypotheses Testing With Reference to the Preferred Model & \\
$\mathrm{H}_{\mathrm{o}}: \ddot{\mathrm{a}}_{3}=0$ & 591.01 & 4.24 & 3.84 & Reject $\mathrm{Ho}_{\mathrm{o}}$ \\
$\mathrm{H}_{\mathrm{o}}: \mathrm{ß}_{6}=0$ & 590.54 & 5.18 & 3.84 & Reject $\mathrm{H}_{\mathrm{o}}$ \\
$\mathrm{H}_{\mathrm{o}}: \ddot{\mathrm{a}}_{1}=0$ & 566.64 & 52.98 & 3.84 & Reject $\mathrm{H}_{\mathrm{o}}$ \\
$\mathrm{H}_{\mathrm{o}}: \ddot{\mathrm{a}}_{2}=0$ & 591.91 & 2.44 & 3.84 & Reject $\mathrm{H}_{\mathrm{o}}$ \\
\hline
\end{tabular}

Level of significance $=5 \%$. 
Table 9: Spearman Rank Correlation Matrix for Rankings of Nebraska School Districts by Cost Efficiency.*

\begin{tabular}{|c|c|c|c|c|c|c|}
\hline & $\begin{array}{l}\text { Cross-section } \\
\text { Ranking } 1989\end{array}$ & $\begin{array}{l}\text { Cross-section } \\
\text { Ranking } 1990\end{array}$ & $\begin{array}{l}\text { Cross-section } \\
\text { Ranking } 1991\end{array}$ & $\begin{array}{l}\text { Pooled } \\
\text { Ranking } 1989\end{array}$ & $\begin{array}{l}\text { Pooled } \\
\text { Ranking } 1990\end{array}$ & $\begin{array}{l}\text { Pooled Ranking } \\
1991\end{array}$ \\
\hline $\begin{array}{l}\text { Cross-section Ranking } \\
1989\end{array}$ & 1.0000 & & & & & \\
\hline $\begin{array}{l}\text { Cross-section Ranking } \\
1990\end{array}$ & 0.81394 & 1.0000 & & & & \\
\hline $\begin{array}{l}\text { Cross-section Ranking } \\
1991\end{array}$ & 0.76670 & 0.81581 & 1.0000 & & & \\
\hline Pooled Ranking 1989 & 0.96345 & 0.72143 & 0.74529 & 1.0000 & & \\
\hline Pooled Ranking 1990 & 0.81875 & 0.82410 & 0.81834 & 0.86010 & 1.0000 & \\
\hline Pooled Ranking 1991 & 0.72194 & 0.70241 & 0.95272 & 0.75905 & 0.84389 & 1.0000 \\
\hline
\end{tabular}

* The null hypothesis that there is no association between rankings is rejected.

Table 10: Effect of Incorporating Efficiency Factor Directly into the School Aid Formula

\begin{tabular}{|c|c|c|c|c|c|c|}
\hline & \multicolumn{6}{|c|}{ Hayes Center Public Schools in 1989-90 } \\
\hline Cost Efficiency & \multicolumn{6}{|c|}{1.244 (based on cross section model) } \\
\hline Actual Cost & \multicolumn{6}{|c|}{$\$ 6731.62 /$ pupil $=\mathrm{f}\left(\mathrm{y}_{\mathrm{i}}, \mathrm{p}_{\mathrm{i}}, \mathrm{ENF}_{\mathrm{i}}, \beta\right) \exp \left(v_{\mathrm{i}}+u_{\mathrm{i}}\right)$} \\
\hline Frontier Cost & \multicolumn{6}{|c|}{$\$ 5411.27 /$ pupil $=\mathrm{f}\left(\mathrm{y}_{\mathrm{i}}, \mathrm{p}_{\mathrm{i}}, \mathrm{ENF}_{\mathrm{i}}, ß\right) \exp \left(v_{\mathrm{i}}\right)$} \\
\hline Cost of Inefficiency & \multicolumn{3}{|c|}{$\$ 1320.35 /$ pupil } & & & \\
\hline \multicolumn{7}{|c|}{ All costs are in current $\$$ of $1989-90$. } \\
\hline & Omaha & Lincoln & Kearney & Ainsworth & Kimball & Falls City \\
\hline Actual Cost & 4631.79 & 4478.13 & 3335.21 & 4008.55 & 5239.50 & 4045.08 \\
\hline Efficiency Factor & 1.030 & 1.037 & 1.031 & 1.060 & 1.139 & 1.061 \\
\hline Stochastic Frontier Cost & 4492.95 & 4317.10 & 3233.17 & 3781.29 & 4596.45 & 3811.79 \\
\hline $\mathrm{F}\left(\mathrm{y}_{\mathrm{i}}, \mathrm{p}_{\mathrm{I}}, \mathrm{ENF}_{\mathrm{i}}, \beta\right)$ & 4778.88 & 4417.82 & 3446.13 & 3627.93 & 4197.25 & 3756.94 \\
\hline Cost of Inefficiency & 138.84 & 161.03 & 102.04 & 227.26 & 643.05 & 233.29 \\
\hline Benefit of Favorable Conditions & 285.93 & 100.72 & 212.96 & --- & --- & --- \\
\hline Cost of Unfavorable Conditions & --- & --- & --- & 153.36 & 339.20 & 54.85 \\
\hline
\end{tabular}

All costs and benefits per pupil are in current $\$$ of 1989-90. 


\section{References}

Afriat, S.N. 1972. Efficiency Estimation of Production Functions, International Economic Review, Vol. 13, No. 3, (October).

Barrow, M.M. 1991. Measuring Local Education Authority Performance: A Frontier Approach, Economics of Education Review, Vol. 10, No. 1, p. 19-27.

Battese, G.E. 1992. Frontier Production Functions and Technical Efficiency: A Survey of Empirical Applications in Agricultural Economics, Agricultural Economics, Vol. 7, p. 185-208.

Battese, G.E. and T.J. Coelli. 1992. Frontier Production Functions, Technical Efficiency and Panel Data: With Application to Paddy Farmers in India, The Journal of Productivity Analysis, Vol. 3, p. 153169.

Battese, G.E. and T.J. Coelli. 1993. A Stochastic Frontier Production Function Incorporating a Model for Technical Inefficiency Effects, Working Papers in Econometrics and Applied Statistics, No. 69, Department of Econometrics, University of New England, Armidale, pp. 22.

Bradbury, et al. 1984. State Aid to Offset Fiscal Disparities Across Communities, National Tax Journal, Vol. 37, (June).

Chakraborty, et al. 1996. Measurement of Technical Efficiency in Public Education: A Stochastic Frontier Production Function Approach, Economic Research Institute Study Paper, ERI \#96-37, Department of Economics, Utah State University, Logan, UT 84322-3530.

Coelli, T.J. 1994. A Guide to Frontier Version 4.1: A Computer Program for Stochastic Frontier Production and Cost Function Estimation. (October) Draft.

Coelli, T.J. 1995. Recent Developments in Frontier Modeling and Efficiency Measurement, Australian Journal of Agricultural Economics, Vol. 39, No. 3.

Coelli, T.J. and G. Battese. 1996. Identification of Factors Which Influence the Technical Inefficiency of Indian Farmers, Australian Journal of Agricultural Economics, Vol. 40, No. 2, (August).

Cohn, E. 1968. Economics of Scale in Iowa High School Operations, Journal of Human Resources, Vol. 3, (Fall).

Cohn, E. 1975. The Economics of Education, Ballinger, Cambridge, Massachusetts.

Coleman, J.S., et al. 1966. Equality of Educational Opportunity: Summary Report, U.S. Government Printing Office, Washington, D.C.

Darlington, J.K. and B.D. Cullen. 1984. Pilot Study of School Examination Performance and Associated Factors, Government Economic Service Working Paper No. 75, London: Department of Education and Science. 
Downes, T.A. and T.F. Pogue. 1994. Adjusting School-Aid Formulas for the Higher Cost of Educating Disadvantaged Students, National Tax Journal, Vol. 47, (March).

Farrell, M.J. 1957. The Measurement of Productive Efficiency, Journal of Royal Statistical Society, Series A, Vol. 120, No. 3.

Gyimah-Brempong, K. and A.O. Gyapong. 1991. Characteristics of Education Production Functions: An Application of Canonical Regression Analysis, Economics of Education Review, Vol. 10, No. 1.

Hanushek, E.A. 1979. Conceptual and Empirical Issues in the Estimation of Educational Production Functions, The Journal of Human Resources, Vol. 14, No. 3.

Hanushek, E.A. 1986. The Economics of Schooling: Production and Efficiency in the Public Schools, Journal of Economic Literature, Vol. 24, (September).

Hanushek, E.A. 1987. Educational Production Functions, Economics of Education: Research and Studies, George Psacharopoulos, ed., Oxford; New York: Pergamon Place.

Hough, J.R. 1981. A Study of School Costs: National Foundation for Educational Research, Nelson, Slough.

Huang, C.J. and J. Liu. 1994. Estimation of a Non-Neutral Stochastic Frontier Production Function, The Journal of Productivity Analysis, Vol. 3.

Hughes, Michael D. 1988. A Stochastic Frontier Cost Function for Residential Child Care Provision, Journal of Applied Econometrics, Vol. 3.

Husen, Torsten, and T. Neville Postlethwaite, editors. 1989. The International Encyclopedia of Education: Research and Studies, Supplementary Volume 2. Pergamon Press, Oxford.

Jimnez, E. 1986. The Structure of Educational Costs: Multiproduct Cost Functions for Primary and Secondary Schools in Latin America, Economics of Education Review, Vol. 5, No. 1.

Klitgaard, R.E. and G.R. Hall. 1975. Are There Unusually Effective Schools? Journal of Human Resources, Vol. 10.

Kumbhakar, et al. 1991. A Generalized Production Frontier Approach for Estimating Determinants of Inefficiency in U.S. Dairy Farms, Journal of Business and Economic Statistics, Vol. 9.

Levin, H.M. 1976. Concepts of Economic Efficiency and Educational Production, in J.T. Froomkin, D.T. Jamison, and R. Radner (eds.), Education as an Industry. Ballinger Press, Cambridge, MA.

Levit, M. and M. A. S. Joyce. 1987. The Growth and Efficiency of Public Spending, Cambridge University Press.

Lewis, W.C. and K. Chakraborty. 1996. Scale Economies in Public Education, Journal of Regional Analysis and Policy, Vol. 26, No. 1. 
Loxley, W. 1987. Wastage in Education, Economics of Education: Research and Studies, George Psacharopoulos, ed., Oxford: New York: Pergamon Place.

McCarty, T.A. and S. Yaiswarng. 1993. Technical Efficiency in New Jersey School, Chapter 10 in Fried, et al. (eds), The Measurement of Production Efficiency: Techniques and Applications. New York: Oxford University Press.

Nebraska Department of Education (NDE), Office of School Finance. Valuation, Levy, Spending, Aid Data for 1988-89 through 1991-92, including only K-12 Districts that Existed all Four Years.

Nebraska Department of Education (NDE), (1989-92). Salary Statistics for Public District Personnel Who Serve Exclusively as Teachers.

Nebraska Department of Education (NDE), (1989-92). Special Education Office. Nebraska Special Education Statistical Report.

Nebraska Department of Education (NDE), (1989-90 to 1991-92). Data on Cost, Average Daily Membership and Graduation Rate.

Nebraska School Finance Review Committee, Annual Report, March 1, 1992.

Nebraska School Finance Review Commission. 1990. Funding Nebraska's Schools: Toward a More Rational and Equitable School Finance System for the 1990's. Final report to the Nebraska State Legislature, January 1, 1990.

Ratcliffe, K., et al. 1990. The Fiscal Condition of School Districts in Nebraska: Is Small Beautiful? Economics of Education Review, Vol. 9, No. 1.

Reifschneider, D. and R. Stevenson. 1991. Systematic Departure from the Frontier: A Framework for the Analysis of Firm Inefficiency, International Economic Review, Vol. 32, No. 3, (August).

Riew, J. 1966. Economies of Scale in High School Operations, Review of Economics and Statistics, Vol. 48 , No. 8, (August).

Schmidt, P. 1985-86. Frontier Production Function. Econometric Reviews, Vol. 4, No. 2, p. 289-328.

Schmidt, P. and C.A.K. Lovell. 1979. Estimating Technical and Allocative Inefficiency Relative to Stochastic Production and Cost Frontiers, Journal of Econometrics, Vol. 9, p. 343-366.

Sengupta, J.K. and R.E. Sfeir. 1986. Production Frontier Estimates of Scale in Public School in California, Economics of Education Review, Vol. 5, No. 3.

Verry, D.W. 1987. Educational Cost Functions, Economics of Education: Research and Studies, George Psacharopoulos, ed., Oxford; New York: Pergamon Place.

Woodhall, M . 1987a. Cost Analysis in Education, Economics of Education: Research and Studies, 
George Psacharopoulos, ed., Oxford; New York: Pergamon Place.

Woodhall, M. 1987b. Economics of Education: A Review, Economics of Education: Research and Studies, George Psacharopoulos, ed., Oxford; New York: Pergamon Place.

Wyckoff, J.H. and J. Lavinge. 1991. The Relative Efficiency of Public Elementary Schools in New York. Working Paper, State University of New York, Albany. 


\section{APPENDIX: THE DATA SET}

\section{Description of the Data}

The period 1989-90 through 1991-92 was chosen as the time frame for the study. There were 274 K-12 school districts in operation during the time period. For these school districts, a data set containing the following variables was constructed: DPP, ADM, GR, AVGS, SP, and EDX. There were 280, 277, and 277 K-12 school districts in Nebraska in 1989-90, 1990-91, and 1991-92 respectively. Thus, the data set includes nearly all of the K-12 school districts in each of three years.

Summary statistics for the data set are presented in Tables A.1, A.2, and A.3. Disbursement per pupil (DPP) includes the following: disbursements for administration, instruction, principal, operation, maintenance, and transportation. Average daily membership (ADM) is a measure of average attendance of students in a school district. Graduation rate (GR) is based on the number of graduates out of the number of seniors in a given year. Teachers' average salary (AVGS) statistics were calculated for teachers who meet the following criteria: teach in public schools, hold a contract, teach in only one district, and have at least 170 contract days. The measure of special education students (SP) in a year for a school district was defined as the ratio of total disabled students to total enrollment in that year. Total disabled students include: students with behavioral disorder (BD), deafblindness (DB), hearing impairments (HI), mental handicap (MH), multiple impairments (MI), orthopedic impairments (OI), other health impairments (OHI), specific learning disabilities (SLD), speech-language impairments (SLI), and visual impairments (VI). Average educational experience of teachers (EDX) is a proxy of teaching skill. 
Table A.1: Summary Statistics for Nebraska School Districts (1989-90)

\begin{tabular}{|c|c|c|c|c|c|}
\hline Variable & $\begin{array}{l}\text { Number of } \\
\text { Districts }\end{array}$ & Mean & $\begin{array}{l}\text { Standard } \\
\text { Deviation }\end{array}$ & Minimum & Maximum \\
\hline Disbursement per pupil (\$) & 274 & $4,975.90$ & $1,214.60$ & $3,091.40$ & 11,208 \\
\hline $\begin{array}{l}\text { Average daily membership } \\
\text { (number of students) }\end{array}$ & 274 & 901.68 & $3,166.70$ & 70.46 & 40,056 \\
\hline Graduation Rate (\%) & 274 & 92.66 & 12.87 & 35.71 & 100 \\
\hline $\begin{array}{l}\text { Average salary per full-time } \\
\text { equivalent teacher }(\$)\end{array}$ & 274 & 22,991 & $2,594.80$ & 16867 & 32,810 \\
\hline $\begin{array}{l}\text { Proportion of special-need category } \\
\text { students (Ratio) }\end{array}$ & 274 & 0.11099 & $3.74 * 10^{-2}$ & $3.00 * 10^{-2}$ & 0.25 \\
\hline Valuation per resident student (\$) & 274 & $0.22781 * 10^{6}$ & 98,902 & 8242 & $5.95 * 10^{5}$ \\
\hline $\begin{array}{l}\text { Average educational experience of } \\
\text { teachers (Year) }\end{array}$ & 274 & 13.538 & 2.763 & 5.70 & 22.50 \\
\hline
\end{tabular}

Table A.2. Summary Statistics for Nebraska School Districts (1990-91)

\begin{tabular}{|c|c|c|c|c|c|}
\hline Variable & $\begin{array}{l}\text { Number of } \\
\text { Districts }\end{array}$ & Mean & $\begin{array}{l}\text { Standard } \\
\text { Deviation }\end{array}$ & Minimum & Maximum \\
\hline Disbursement per pupil (\$) & 274 & $5,205.60$ & $1,259.10$ & $3,434.70$ & 10,219 \\
\hline $\begin{array}{l}\text { Average daily membership } \\
\text { (number of students) }\end{array}$ & 274 & $9,14.92$ & $3,224.70$ & 60.68 & 40,678 \\
\hline Graduation Rate (\%) & 274 & 96.053 & 6.027 & 50 & 100 \\
\hline $\begin{array}{l}\text { Average salary per full-time } \\
\text { equivalent teacher }(\$)\end{array}$ & 274 & 23,857 & $2,655.70$ & 18,371 & 34,303 \\
\hline $\begin{array}{l}\text { Proportion of special-need category } \\
\text { students (Ratio) }\end{array}$ & 274 & 0.11712 & $4.54 * 10^{-2}$ & $2.00 * 10^{-2}$ & 0.32 \\
\hline Valuation per resident student (\$) & 274 & $0.24441 * 10^{6}$ & $1.07 * 10^{5}$ & 10,968 & $5.74 * 10^{5}$ \\
\hline $\begin{array}{l}\text { Average educational experience } \\
\text { of teachers (Year) }\end{array}$ & 274 & 13.832 & 2.595 & 6.20 & 20.10 \\
\hline
\end{tabular}

Table A.3. Summary Statistics for Nebraska School Districts (1991-92)

\begin{tabular}{|c|c|c|c|c|c|}
\hline Variable & $\begin{array}{l}\text { Number of } \\
\text { Districts }\end{array}$ & Mean & $\begin{array}{l}\text { Standard } \\
\text { Deviation }\end{array}$ & Minimum & Maximum \\
\hline Disbursement per pupil (\$) & 274 & $5,401.20$ & $1,338.60$ & $3,607.70$ & 12,649 \\
\hline $\begin{array}{l}\text { Average daily membership } \\
\text { (number of students) }\end{array}$ & 274 & $9,34.80$ & $3,291.20$ & 56.60 & 41,314 \\
\hline Graduation Rate (\%) & 274 & 95.99 & 5.631 & 66.67 & 100 \\
\hline $\begin{array}{l}\text { Average salary per full-time equivalent } \\
\text { teacher }(\$)\end{array}$ & 274 & 24,644 & $2,736.80$ & 17,997 & 35,109 \\
\hline $\begin{array}{l}\text { Proportion of special-need category } \\
\text { students (Ratio). }\end{array}$ & 274 & 0.11748 & $5.06 * 10^{-2}$ & $3.00 * 10^{-2}$ & 0.68 \\
\hline Valuation per resident student (\$) & 274 & $0.24830 * 10^{6}$ & $1.13^{*} 10^{5}$ & 9,049 & $7.75^{*} 10^{5}$ \\
\hline $\begin{array}{l}\text { Average educational experience of } \\
\text { teachers (Year). }\end{array}$ & 274 & 14.062 & 2.717 & 3.0 & 21.20 \\
\hline
\end{tabular}

Source: Nebraska Department of Education. 